\title{
Penyelesaian Antara Nasabah dan Pihak Bank Perkreditan Rakyat (BPR) Dalam Perkara Tunggakan Pembayaran Kredit
}

\author{
Nindya Febrina Nurhapsari ${ }^{1 *}$, Rani Apriani ${ }^{2}$ \\ ${ }^{12}$ Fakultas Hukum Universitas Singaperbangsa Karawang \\ e-mail : nindyafebrinanurhapsari@gmail.com, rani.apriani180488@gmail.com \\ *Corresponding author
}

Article info

Received: Apr 19, 2021 Revised: May 14, 2021 Accepted: May 22, $2021 \quad$ Published: Jun 10, 2021

DOI: https://doi.org/10.31599/krtha.v15i1.568

Keywords : Agreement, Credit, Bank Perkereditan Rakyat

Abstract : People's Credit (BPR) is a financial institution that collects funds from the public in the form of savings and distributes them in the form of credit. Bank Perkeditan Rakyat (BPR) in providing loans to customers must meet certain conditions, and usually Rural Banks (BPR) provide different loan terms depending on their professional status. In every case of lending and borrowing or you could say credit, there are many customers who in practice do not meet the agreed time in repaying their loans for various reasons, resulting in problematic credit. Non-performing loans are usually divided into 3 things, namely (1) Substandard, (2) Doubtful, (3) Loss. Usually the customer is more directed towards bad credit. Writing this article aims to analyze how the initial process of the agreement between the customer and the People's Credit Bank (BPR) in providing loans and how is the settlement between the customer and the People's Credit Bank in cases of arrears in credit payments. This study uses a normative juridical method. The type of data used in this research is secondary data obtained through library research, legal materials used. The data collection technique in this research is to use literature study. The data collected is then processed and systematized according to the order of the problems and finally analyzed. All data obtained by the author, such as books, articles, banking journals, and internet sites related to the object being written, were analyzed using the normative juridical method.

Kata kunci : Perjanian, Kredit, Bank Perkreditan Rakyat (BPR)

Abstrak : Perkreditan Rakyat (BPR) merupakan Lembaga keuangan yang menghimpun dana dari masyarakat dalam bentuk simpanan dan menyalurkan kembali dalam bentuk kredit. Bank Perkreditan Rakyat (BPR) dalam memberikan pinjaman kepada Nasabah harus memenuhi syarat-syarat tertentu, dan biasanya Bank Perkreditan Rakyat (BPR) memberikan syarat Pinjaman berbeda-beda tergantung dengan status profesinya. Dalam setiap kejadian pinjam-meminjam atau bisa dibilang kredit, banyak sekali Nasabah yang dalam prakteknya tidak menepati waktu yang diperjanjikan dalam mengembalikan pinjamannya dengan berbagai alasan, sehingga timbulah kredit yang bermasalah. Kredit yang bermasalah ini biasanya dibedakan menjadi 3 hal antara lain yaitu (1) Kurang Lancar, (2) Diragukan, (3) Macet. Biasanya Nasabah lebih mengarah kepada kredit yang macet. Penulisan artikel ini bertujuan untuk menganalisis bagaimana Bagaimana proses awal Perjanjian antara nasabah dan pihak Bank Perkreditan Rakyat (BPR) dalam memberikan pinjaman 
dan Bagaimana penyelesian antara Nasabah dan pihak Bank Perkreditan Rakyat dalam perkara tunggakan pembayaran kredit. penelitian ini menggunakan metode yuridis normatif. Jenis data yang digunakan dalam penelitian ini adalah data sekunder yang diperoleh melalui studi kepustakaan, bahan-bahan hukum yang digunakan. Teknik pengumpulan data dalam penelitian ini adalah dengan menggunakan studi kepustakaan. Data yang terkumpul selanjtnya diolah dan sistematisasi sesuai dengan urutan permasalahan dan akhirnya dianalisis. Seluruh data diperoleh penulis sepeti buku, artikel-artikel, jurnal perbankan, serta situs-situs internet yang berkaitan dengan objek yang ditulis, dianalisis dengan menggunakan metode yuridis normatif.

\section{PENDAHULUAN}

Manusia atau orang merupakan subjek dalam sebuah kegiatan, seperti salah satunya kegiatan perekonomian, dimana setiap orang yang membahas perekonomian selalu menjurus kepada masalah-masalah yang berhubungan dengan kebutuhan hidupnya. Upaya manusia dalam memenuhi kehidupan yang paling mendasarpun dipengaruhi ole aspek sosial dan budaya yang ada saat ini. Setiap tingkatan lapisan kondisi masyarakat tentu berbeda-beda satu dengan yang lainnya.

Saat ini, semua negara di dunia sudah tidak asing lagi dengan sebutan "bank". Namun, untuk memberikan definisi yang tepat tentang bank, diperlukan elaborasi lebih lanjut Mengapa ? karena definisi bank penyedia dapat dilihat dari berbagai sudut. Oleh karena itu, secara garis besar pengertian bank menurut ahli dan hukum akan dijelaskan secara rinci

Menurut A. Abdurrachman, mengemukakan perbankan (banking) pada umumnya ialah sebuah kegiatan-kegiatan dalam menjual-belikan mata uang, surat efek dan instrument-instrument yang dapat diperdagangkan. Penerimaan deposito, untuk memudahkan penyimpananya atau untuk mendapatkan bunga, dan/atau pembuatan, pemberian pinjaman-pinjaman dengan atau tanpa barang-barangtanggungan, penggunaan uang ditempatkan atau diserahkan untuk disimpan. Pembelian, penjualan, penukaran, atau penguasaan atau penahanan alat pembayaran, instrument yang dapat diperganagkan, atau benda-benda lainnya yang mempunyai nilai moneter secara langsung sebagai suatu kegiatan yang diatur.

Sementara itu dalam Pasal 1 angka 1 Undang-Undang Nomor 7 Tahun 1992 Tentang Perbankan, sebagaimana telah diubah dengan Undang-Undang No. 10 Tahun 1998 (selanjutnya disingkat dengan Undang-Undang Perbankan) yang berisi bahwa “ Perbankan adalah segala sesuatu yang menyangkut tentang bank, mencakup kelembagaan, kegiatan usaha, serta cara proses dalam melaksanakan keggiatan usaha; sedangkan 
pengertian bank dijelaskan dalam Pasal 1 angka 2 UUP berisi bahwa " Bank addalah badan usaha yang menghimpun dana dari masyarakatdalam bentuk simpanan dan menyalurkannya kepada masyarakat dalam bentuk kredit dan/atau bentuk-bentuk lainnya dalam rangka meningkatkan taraf hidup rakyat banyak. ${ }^{1}$

Sebelum berlakunya Undang-Undang Nomor 7 Tahun 1992 bahwasannya bank dapat digolongkan berdasarkan jenis kegiatan usahanya, seperti bank tabungan, bank pembangunan dan bank ekspor-impor. Namun setelah Undang-Undang tersebut berlaku, jenis bank yang diakui secara resmi hanya terdiri atas dua (2) jenis, yaitu Bank Umum dan Bank Perkreditan Rakyat (BPR).

Bank Umum didefinisikan oleh Undang-Undang Nomor 10 Tahun 1998 sebagai bank yang melaksanakan kegiatan usaha secara konvensional dan/atau berdasarkan prinsip Syariah yang dalam kegiatannya memberikan jasa dalam lalu lintas pembaarannya sedangkan Bank Perkredian Rakyat (BPR) didefinisikan oleh Undang-Undang Nomor 10 Tahun 1998 sebagai Bank yang melaksanakan kegiatan usaha secara konvensional dan/atau berdasarkan syariah yang dalam kegiatannya tidak memberikan jasa dalam lalu lintas pembayarannya. ${ }^{2}$

Selama ini sistem kinerja antara Bank umum dan Bank Perkreditan Rakyat (BPR) tidak jauh berbeda, sehingga Bank Perkreditan Rakyat (BPR) juga merupakan Bank resmi, fungsinya tidak hanya untuk memberikan kredit kepada pengusaha mikro kecil dan menengah, tetapi juga untuk menyediakannya. dengan kredit. Deposito / nasabah publik. Dalam mengalokasikan kredit kepada nasabah harus menggunakan prinsip 3T yaitu tepat waktu sesuai jumlah yang benar dan sesuai tujuan karena proses kredit relatif cepat, persyaratan lebih sederhana, dan benar-benar memahami nasabah.

Kegiatan Bank Perkreditan Rakyat (BPR) jauh lebih sempit dibandingkan kegiatan Bank umum. Karena Bank Perkreditan Rakyat (BPR) dalam melakukan kegiatannya tidaksama dengan kegiatan yang dilakukan bank umum. Keterbatasan kegiatan Bank Perkreditan Rakyat (BPR) sesuai dengan misi Bank Perkreditan Rakyat (BPR) yang berdasarkan ketentuan Pasal 13 Undang-Undang Perbankan meliputi : (a) Menghimpun dana dari masyarakat dalam bentuk simpanan berupa deposito berjangka, dan atau bentuk lainnya yang dipersamakan itu, (b) memberikan kredit, (c) menyediakan pembiayaan dan penempatan dana berdasarkan prinsip syariah, sesuai dengan ketentuan yang ditetapkan oleh Bank Indonesia. (d) menempatkan dananya dalam bentuk Sertifikat Bank Indonesia

${ }^{1}$ Sembiring, Sentosa. Hukum Perbankan (Bandung, Mandar Maju, 2012), 17-18.

${ }^{2}$ Novi, Amanita. "Bank dan Lembaga Keuangan Lain." Jurnal Universitas Negri Yogyakarta, Bab 4: 
(SBI), deposito bernagka, tabungan, sertifikast deposito, dan atau tabungan pada bank lain. ${ }^{3}$

Selain meminjam ke Bank Perkreditan Rakyat (BPR), nasabah juga harus memberikan jaminan. Hukum penjaminan merupakan rangkaian peraturan terkait penjaminan dalam konteks hutang (dana pinjaman) yang tertuang dalam peraturan perundang-undangan yang berlaku. Pinjaman merupakan salah satu kegiatan usaha bank tradisional yang bertujuan untuk mengelola dana yang dikendalikan untuk produktivitas dan memberikan keuntungan.

Jaminan kredit yang disetujui dan diterima bank, akan mempunyai beberapa fungsi. Salah satunya untuk mengamankan pelunasan kredit bila pihak menjamin cedera janji. Jika kredit yang diterima oleh peminjam tidak dilunasi dan dianggap kredit macet, maka jaminan kredit yang diterima oleh Bank akan digunakan untuk melunasi kredit macet tersebut. Oleh karena itu, penjaminan kredit berperan penting dalam memastikan pengembalian dana bank yang diberikan kepada peminjam melalui kredit. Hal ini dapat dilihat dari praktik perbankan bahwa penjualan (pembayaran) objek penjaminan kredit adalah untuk melunasi kredit macet peminjam. Penjualan jaminan kredit merupakan tindakan yang perlu dilakukan Bank Dunia untuk mendapatkan kembali pembayaran kembali dana yang dipinjamkan. Karena peminjam tidak menjalankan kewajibannya sesuai dengan perjanjian kredit. $^{4}$

Hasil penjualan jaminan kredit akan digunakan untuk melunasi hutang peminjam kepada bank, yang diharapkan dapat meminimalkan kerugian bank dan mematuhi undang-undang dan peraturan sektor perbankan saat ini. Untuk mewujudkan penjualan penjaminan kredit dan mencapai tujuan yang diharapkan Bank Dunia, perlu dilakukan upaya pengamanan, antara lain obyek penjaminan kredit harus sepenuhnya dibatasi melalui ketentuan hukum yang mengatur lembaga penjaminan.

\section{METODE PENELITIAN}

Pendekatan masalah dalam penelitian ini menggunakan metode yuridis normative. Jenis data yang digunakan dalam penelitian ini adalah data sekunder yang diperoleh melalui studi kepustakaan, bahan-bahan hukum yang digunakan. Teknik pengumpulan data dalam

\footnotetext{
${ }^{3}$ Susetiyo Weppy, Pitono. “Tinjauan Yuridis Penyelesaian Kredit Macet pada Bank Perkreditan Rakyat Berkah Patok Kediri, Jawa Timur”. Universitas Islam Balitar 9 No. 2 (2019) 50-51.

${ }^{4}$ Sambe, N Newfriend. "Fungsi Jaminan Terhadap Pemberian Kredit Oleh Pihak Bank Menurut Undang-Undang Nomor 10 Tahun 1998”. Lex Crimen 5, No.4 (2016): 76-77
} 
penelitian ini adalah dengan menggunakan studi kepustakaan. Data yang terkumpul selanjutnya diolah dan disistematisasi sesuai dengan urutan permasalahan dan akhirnya dianalisis. Seluruh data yang diperoleh penulis, seperti buku, artikel-artike, jurnal, undangundang, serta situs-situs internet yang berkaitan dengan objek yang ditulis, dianalisis dengan menggunakan metode yuridis normative.

\section{PEMBAHASAN}

\section{A. Proses Awal Perjanjian antara Nasabah dan Pihak Bank Perkreditan Rakyat (BPR) dalam memberikan Pinjaman}

Bank Perkreditan Rakyat (BPR) adalah lembaga keuangan yang menghimpun dana dari masyarakat dalam bentuk simpanan dan menyalurkannya dalam bentuk kredit. Salah satu bentuk kredit yang dimiliki oleh Bank Perkreditan Rakyat (BPR) adalah pinjaman angsuran yang berlaku baik bagi nasabah legal maupun non legal, namun apabila pinjaman tersebut dapat dijadikan solusi lengkap bagi nasabah yang ingin menambah modal dan Program kebutuhan lainnya. Proses penilaian kelayakan pemberian kredit menjadi kendala yang dihadapi Bank Perkreditan Rakyat (BPR).

Bank Perkreditan Rakyat (BPR) didirikan untuk membantu para pengusaha kecil dan memobilisasi berbagai kepentingan untuk kegiatan mereka, serta menghimpun dana dari masyarakat dalam bentuk tabungan dan deposito. Perjanjian kredit antara bank dan nasabah mengacu pada Pasal 1754 KUH Perdata yang mengacu pada perilaku pemberian kredit bank sebagai kreditur dan nasabah sebagai debitur, Namun, perjanjian kreditur tidak hanya memuat persyaratan pinjaman, tetapi juga kesepakatan yang dicapai antara para pihak dan prinsip perjanjian. Perlu ditekankan di sini bahwa selain dokumen perjanjian, dokumen perjanjian kredit antara bank dan nasabah merupakan perjanjian utama.

Dalam perjanjian kredit bank, hal yang sangat penting adalah tentang jaminan kepada pemberi pinjaman atau bank (letter of credit agency), dan jaminan terkait kredit merupakan salah satu syarat untuk mendapatkan pengajuan kredit. Agunan di sini tidak hanya digunakan untuk barang, tetapi juga menjadi milik debitur, dan bisa juga dalam bentuk bagunan tidak berwujud.

Perjanjian adalah hubungan hukum antara dua pihak mengenai harta benda, di mana salah satu pihak menjanjikan atau dianggap sebagai janji untuk melakukan sesuatu, sedangkan pihak lainnya berhak untuk menggugat atas pelaksanaannya. Agar perjanjian mempunyai kekuatan hukum, maka harus memenuhi persyaratan hukum perjanjian yang tertuang dalam Pasal 1320 Kitab Undang-Undang Hukum Perdata (KUHPer), yaitu 
antara lain (1) mencapai kesepakatan dengan pengikat, (2) mencapai kesepakatan (3) Adanya sesuatu / obyek; (4) Adanya sebab hukum.

Dilihat dari syarat-syarat perjanjian di atas, syarat ini adalah syarat mutlak, dan syarat mutlak harus dicapai sebelum perjanjian bisa ditandatangani. Bagi bank, salah satu alasan yang cukup memadai dari adanya perjanjian pemberian kredit kepada nasabah diperoleh sesuai dengan Pasal 1 Ayat 11 Undang-Undang Nomor 10 Tahun 1998. Rumusnya adalah sebagai berikut:

"Kredit adalah penyediaan uang atau tagihan-tagihan yang dapat dipersamakan dengan itu, berdasarkan persetujuan atau kesepakatan pinjam-meminjam antara bank dengan pibak lain yang mewajibkan pibak peminjam untuk melunasi hutangnya setelah jangka waktu tertentu dengan jumlah bunga, imbalan, atau pembagian hasil keuntungan"

Maksud dicantumkan kalimat perjanjian atau perjanjian pinjaman dalam rumusan klausul di atas memiliki tujuan sebagai berikut: (1) Pembuat undang-undang bermaksud untuk menegaskan bahwa hubungan kredit bank merupakan hubungan kontraktual antara bank dengan nasabah debiturnya dalam bentuk pinjaman. Oleh karena itu, untuk hubungan kredit bank, berlaku buku ketiga (tentang perikatan). Secara umum, Bab 13 KUH Perdata (tentang pinjaman) khususnya (2) pembuat undang-undang bermaksud untuk mensyaratkan pembentukan hubungan kredit bank atas dasar perjanjian tertulis. Namun, jika hanya berdasarkan rumusan ketentuan ini, akan sulit dijelaskan bahwa ketentuan tersebut memang memerlukan kredit bank berdasarkan perjanjian tertulis.

Ketentuan Undang-Undang tersebut harus dikaitkan dengan Instruksi Presedium Kabinet No. 15/EK/IN/10/1966 tanggal 3 Oktober 1966 Jo Surat Edaran Bank Negara Indonesia Unit I No. 2/539/UPK/Pemb. Tanggal 8 Oktober 1966 dan Surat Edaran Bank Negara Indonesia Unit I No. 2/649/UPK/Pemb. Tanggal 20 Oktober 1966 serta Instruksi Presidium Kabinet Ampera No. 10/EK/IN/2/1967 tanggal 6 Februari 1967 yang menentukan bahwa dalam memberikan kredit dalam bentuk apapun perbankan wajib menggunakan atau membuat perjanjian kredit tertulis. ${ }^{5}$

Bank Perkreditan Rakyat (BPR) harus memenuhi persyaratan tertentu untuk memberikan pinjaman kepada nasabah. Biasanya, Bank Perkreditan Rakyat (BPR) memberikan persyaratan pinjaman yang berbeda berdasarkan status profesionalnya. Namun secara umum, persyaratan Bank Perkreditan Rakyat untuk calon debitur yang bersifat pribadi harus memenuhi ketentuan sebagai berikut, seperti fotokopi KTP,

5 Diab, Ashadi. "Perjanjian Kredit pada Bank Perkreditan Rakyat." Institut Agama Islam Negeri Kendari 10 No. 1(2017) 3-6. 
fotokopi akta nikah, fotokopi kartu keluarga., dan buku tabungan yang harus diterbitkan Salinan atau salinan rekening koran. Rekening tersebut harus dimiliki oleh bank di mana calon debitur telah menabung selama tiga bulan terakhir, salinan gaji, tagihan listrik atau air, dan salinan jaminan. Selain pinjaman pribadi, Perkreditan Rakyat Bank juga memberikan pinjaman kepada perusahaan atau badan usaha. Saat membuat letter of credit, syarat dan prosedurnya akan semakin panjang dan rumit.Oleh karena itu, setiap perusahaan dan badan usaha yang ingin membuat letter of credit harus memenuhi persyaratan sebagai berikut: fotokopi KTP pengurus perusahaan, dan Fotokopi izin usaha, fotokopi Nomor Pokok Wajib Pajak (NPWP), fotokopi tanda tangan perusahaan terdaftar, fotokopi akta perusahaan dan anggaran dasar, dan perubahan notaris 3 bulan terakhir, fotokopi buku tabungan bank atau rekening koran perusahaan, data keuangan perusahaan, Misalnya data laporan laba rugi, catatan pembukuan, data penjualan, dll. Terakhir adalah daftar periksa permohonan keuangan nasabah. ${ }^{6}$

Setelah nasabah memenuhi persyaratan di atas, Bank Desa dapat memilih data yang dimasukkan terlepas dari layak atau tidaknya nasabah tersebut mendapatkan kredit. Namun sesuai dengan ketentuan Undang-Undang Nomor 7 Tahun 1992 tentang Penerimaan Kredit, dan Sesuai dengan Pasal 8 Undang-Undang Nomor 7 Tahun 1992, "Dalam hal perluasan kredit, bank umum harus mempunyai kepercayaan terhadap kemampuan debitur untuk mengembalikan kredit. . Hutang yang disepakati. ". Menurut Pasal 8 Undang-Undang Nomor 7 Tahun 1992, kepercayaan bank didasarkan pada penilaian karakter yang cermat. Kemampuan, modal, hipotek prospek bisnis debitur.

Dalam hal ini, ketentuan mengenai debitur tidak secara tegas mengatur bahwa mereka dapat menjadi debitur, tetapi hanya mengatur bahwa mereka yang memperoleh kredit dari kreditur (bank) dalam bentuk hak kreditur wajib mengembalikan kreditur sebagaimana disepakati. waktu. Dengan demikian, dapat disimpulkan bahwa debitur adalah orang perseorangan atau badan usaha yang menerima kredit dan wajib mengembalikan kredit tersebut setelah jangka waktu yang telah ditentukan. Selain itu, sebelum memberikan kredit, bank biasanya memberikan syarat dan prosedur yang meliputi 5 jenis, diantaranya :

a. Permohonan Kredit

Pengajuan kredit biasanya mencakup pengajuan baru untuk jenis mekanisme kredit, pengajuan mekanisme kredit lain yang sedang berjalan, pengajuan

${ }^{6}$ PT. BPR Karya Bakti Sejahtera “Cara Pinjam Uang di Bank Perkreditan Rakyat (BPR)." 9 Mei 
perpanjangan atau perpanjangan kredit masa lalu yang sudah habis masa berlakunya, pengajuan lain untuk mengubah syarat jalur kredit yang sedang berjalan, dan jaminan lainnya. penukaran, Perubahan atau penundaan jadwal cicilan, dll.

Umumnya dalam mengevaluasi permohonan kredit, bank perlu memperhatikan prinsip bahwa bank memberikan antrian kredit. (1) Bank hanya memberikan kredit pada saat mengajukan permohonan kredit secara tertulis. ) Permohonan kredit harus memuat informasi yang lengkap dan memenuhi persyaratan bank lain.

(3) Bank harus memastikan keakuratan data dan informasi yang disampaikan dalam permohonan kredit.

b. Penyidikan Analisis Kredit

Dalam rangka melakukan investigasi dan analisis kredit, bank biasanya melakukan berbagai tugas, antara lain (1) wawancara dengan pemohon kredit atau debitur; (2) mengumpulkan data terkait permohonan kredit yang diajukan oleh nasabah, termasuk data internal bank dan data eksternal. Ini termasuk informasi antar bank dan pemeriksaan daftar hitam dan daftar kredit buruk, (3) pemeriksaan atau investigasi atas kebenaran dan kewajiban masalah yang diajukan oleh pelanggan, dan informasi lain yang diperoleh.

Bank akan mengambil keputusan berdasarkan analisis kreditnya dan menolak atau menyetujui permintaan calon debitur. Oleh karena itu, setiap analisis kredit harus mencakup penilaian yang lengkap dan lengkap agar dapat dipertanggungjawabkan sesuai dengan ketentuan internal bank dan peraturan perundang-undangan lainnya.

c. Keputusan atas Permohonan Kredit

Keputusan kredit biasanya merupakan keputusan tim. Demikian pula untuk kredit yang ditolak, surat penolakan harus dikirimkan sesuai dengan alasannya masingmasing. Dalam pengambilan keputusan setiap pengajuan kredit, perhatian harus diberikan pada evaluasi dan ketentuan umum yang pada dasarnya tercantum dalam laporan pemeriksaan kredit dan analisis kredit. Keputusan kredit dalam hal ini untuk menentukan apakah kredit diberikan atau ditolak (jika diterima), dan otoritas yang berwenang siap.

d. Persetujuan Permohonan Kredit

Persetujuan pengajuan kredit merupakan keputusan bank untuk mengabulkan atau seluruh pengajuan kredit dari calon nasabah. Untuk melindungi kepentingan 
bank dalam pelaksanaan perjanjian, untuk membayar batas kreditnya sendiri, biasanya setiap transaksi menggunakan kredit yang disetujui bank. Padahal, pembayaran kredit ini dalam bentuk pembayaran dan / atau kemudahan lainnya. Bank menyetujui pembayaran kredit nasabah hanya jika persyaratan yang harus dipenuhi nasabah tersebut.

e. Pelunasan Fasilitas Kredit

Pelunasan kredit merupakan dipenuhinya semua kewajiban utang nasabah terhadap bank yang berkaitan hapusnya perjanjian kredit. ${ }^{7}$

\section{B. Penyelesaian Antara Nasabah dan Pihak Bank Perkreditan Rakyat (BPR) dalam perkara Tunggakan Pembayaran Kredit}

Sebagai perwujudan bisnis perbankan, Bank Perkreditan Rakyat (BPR) harus mampu menunjukkan kepercayaan nasabah (deposan) terhadapnya. Jika terjadi kredit macet, maka setiap dana yang dikeluarkan sebagai pinjaman kredit akan menanggung tanggung jawab yang sangat besar. Salah satu dampak utama dari kredit macet adalah kerugian yang dialami bank, beberapa bank terancam bangkrut. Idealnya, Bank Perkreditan Rakyat (BPR) memberikan formula kredit tertentu dengan syarat yang harus dipenuhi oleh pemohon kredit. Meskipun pemohon kredit memenuhi persyaratan yang diajukan, namun tidak dapat ditentukan apakah bank memberikan layanan kredit. Bank Perkreditan Rakyat (BPR) harus terlebih dahulu mempelajari dan menganalisis status pemohon kredit. Dalam memberikan kredit, Bank Perkreditan Rakyat (BPR) harus berpegang pada prinsip pemberian kredit yang baik. Untuk memperoleh keyakinan tersebut, misalnya pada saat melakukan penyesuaian terhadap Pasal 8 UU Perbankan, karakteristik ekonomi debitur, kapabilitas, permodalan, bagunan dan kondisi (kondisi ekonomi) harus dikaji secara cermat.

Dalam hal setiap jenis pinjaman atau bisa dikatakan kredit, sebenarnya banyak nasabah yang gagal mengembalikan pinjaman pada waktu yang telah disepakati karena berbagai alasan, yang menyebabkan kredit bermasalah. Kredit bermasalah biasanya dibagi menjadi tiga kategori: (1) Wajar Tanpa Pengecualian, (2) mencurigakan, dan (3) Macet. Biasanya nasabah lebih cenderung kredit macet.

Kredit macet atau kredit bermasalah adalah pinjaman yang sulit dilunasi karena

\footnotetext{
${ }^{7}$ Sambe, Newfriend N. "Fungsi Jaminan Terhadap Pemberian Kredit oleh pihak Bank Menurut Undang-Undang Nomor 10 Tahun 1998.” Lex Crimen 5 Nomor 4 (2016)
} 
faktor atau faktor yang disengaja atau karena kondisi yang tidak dapat ditanggung oleh debitur. Setiap bank sangat mengkhawatirkan reputasi buruk tersebut, karena akan merusak keadaan keuangan bank bahkan dapat menyebabkan kegiatan usaha bank terhenti. Munculnya kredit macet, pada dasarnya tidak terjadi secara tiba-tiba, melainkan melalui suatu proses. Terjadinya kredit macet biasanya disebabkan oleh dua hal, antara lain kreditor (bank) dan debitur. Jika debitur gagal memenuhi agunan yang tercantum dalam perjanjian kredit dan kredit macet, debitur harus dinyatakan gagal bayar terlebih dahulu sebelum agunan diberlakukan, hal ini dilakukan melalui putusan pengadilan. Oleh karena itu, kreditur harus menuntut debitur atas pelanggaran kontrak. Namun, sebelum menggugat debitur, kreditur harus terlebih dahulu mengajukan somasi yang memuat isinya agar debitur dapat melaksanakan kewajibannya. Jika debitur gagal melaksanakan kewajibannya untuk melaksanakan kontrak, kreditur dapat menuntut debitur atas pelanggaran kontrak.Jika pengadilan menetapkan bahwa debitur telah melanggar kontrak, maka debitur (pelanggan) akan mengeksekusi agunan. Dasar wanprestasi, jika pengadilan memutuskan debitur wanprestasi maka jaminan yang diberikan debitur (nasabah) akan dieksekusi.

Bahwasannya sebelum dilakukan eksekusi Nasabah diberikan Surat Pemberitahuan kesatu, kedua dan menelpon debitur agar melunasi angsuran yang sedang dijalani, jika debitur tidak merespon pihak bank akan mendatangkan kerumahnya dan jika rumah tersebut kosong tanpa penghuni pihak bank akan memberikan Surat Peringakatan (SP). Surat Peringatan ini diberikan oleh Bank agar Nasabah tidak lupa akan kredit atau utang yang sudah kedaan macet. Biasanya Bank Perkreditan Rakyat (BPR) sebelum melakukan eksekusi terhadap barang yang akan dilelang secara umum memberikan prosedur antara lain :

1. Memberitahukan adanya keterlambatan pembayaran

Bank tidak serta-merta menyita asset milik Nasabah saat Bank mendapatkan cicilan menunggak. Bank akan memberitahukannya terlebih dahulu lewat sebuah surat yang berisi cicilan pokok, bunga, dan berapa lama cicilan terlambat bayar. Atau simpelnya menelepon nasabah pada jam operasional bank. Dan juga surat pemberitahuan (SP) dikirimkan sekali sebulan, sementara panggilan telepon dilakukan sekali seminggu. Jika belum juga membayar, maka bank akan lebihh sering mengirimkan surat dan menelepon sampai nasabah melakukan pembayaran yang seharusnya. Jika tidak juga dilakukan pembayaran maka bank akan mengirimkan salah seorang karyawan untuk menagih piutang kepada nasabah.

2. Menalayangkan Surat Peringatan 
Jika poin nomor satu tidak juga berhasil, maka bank akan melayangkan surat peringatan terkait utang. Surat ini sufatnya lebih keras daripada surat pemberitahuan maupun teguran dari karyawan bank, yng inntensitas kirimanya bisa mencapai tiga kali dalam seminggu.

Surat peringatan ini terdiri dari tiga level. Pertama, biasanya berisi keterangan berapa penurunan level kredit, dari yang tadinya lancer menjadi kurang lancer dan dalam perhatian khusus. Kedua, mengubah keterangan kredit dari mendapatkan perhatian khusus menjadi diraugkan karena nasabah sendiri tidak menggubris peringatan dari bank. Ketiga, status kredit berubah menjadi macet yang mana catatan kredit ini akan langsung terekam dari Bank Indonesia. Apabila kredit sudah macet, maka nasabah sulituntuk mendapatkan pinjaman di lain waktu karena bank sendiri akan sanat penuh pertimbangan sebelum memberikan pinjaman.

3. Aset akan Disita

Jika surat pemberitahuan dan peringatan diatas diabaikan, maka bank terpaksa menyita aset yang dimiliki nasabah. Banyaknya aset yang disita tergantung dari total sisa utang yang seharusnya dibayarkan. Semakin besar sisanya, maka semakin banyak aset yang mungkin disita oleh pihak bank. ${ }^{8}$

Di Indonesia belum semua yurisdiksi memiliki balai lelang, artinya masih banyak pengadilan negeri yang memiliki balai lelang di luar kota. Misalnya, kabupaten yang tidak memiliki rumah lelang sendiri akan kesulitan melakukan lelang, sehingga jika akan diadakan lelang harus memberitahukan kepada balai lelang nasional di daerah lain yang ada rumah lelang tersebut. Keengganan masyarakat untuk berpartisipasi dalam lelang atau menjadi pendukung lelang menghalangi proses penegakan hukum. Lelang merupakan penjualan barang yang terbuka untuk umum dengan penaaran harga secara tertulis dan/atau lisan yang semakin meningkat atau menurun untuk mencapai harga tertinggi yang didahului dengan pengumuman lelang. Lelang memiliki tiga jenis antara lain (1) Lelang Eksekusi merupakan lelang untuk melaksanakan putusan atau penetapan pengadilan, dokumen-dokumen yang dipersamakan dengan itu, dan/atau melaksanakan ketentuan dalam peraturan perundang-undangan, (2) Lelang Non Eksekusi Wajib merupakan lelangg untuk melaksanakan penjualan barang yang oleh peraturan perundangundangan diharuskan dijual secara lelang, (3) Lelang Non Eksekusi Sukarela merupakan

${ }^{8}$ Hadijah, Siti "Prosedur Penyitaan Aset yang Dilakukan Oleh Bank" 3 September 2020 
lelang atas barang milik swasta perseorangan atau badan hukum/badan usaha yangg dilelang secara sukarela. ${ }^{9}$

\section{Kasus Lelang}

Berdasarkan kasus yang saya temui mengenai Debitur yang tidak bisa melanjutkan pembayaran kredit kepada Bank swasta yaitu Bank Perkreditan Rakyat (BPR). Dengan pelafon pinjaman sebesar Rp. 240.000.000 dengan tenor waktu 5 tahun dimuai pada tahun 2018.

Debitur ini bernama sukardi dan mempunyai usaha yang bergerak di bidang kontraktor yang bernama "CV. Triyuda Air Conditioning", kemampuan pembayaran debitur mengalami penurunan pada bulan keempat. Dimana pada bulan kesatu sampai ketiga debitur membayar angsuran dengan benar namun pada bulan keempat debitur tidak membayar angsuran sehingga hal ini mempengaruhi penghasilan debitur untuk membayar kewajiban. Sebelum Tanah yang dijaminkan debitur di lelang Pihak Bank Perkreditan Rakyat (BPR) sudah memberikan Surat Pemberitahuan tetapi pihak debitur tidak merespon bahkan saat diberikan Surat Peringatan untuk kedua kalinya debitur tetap tidak merespon dan memblokir nomor pihak Bank Perkreditan Rakyat (BPR) dan untuk terakhir kalinya pihak bank mendatangkan rumah debitur tetapi rumah tersebut terkunci dan tidak ada orang. oleh karena itu pihak Bank mendaftarkan Tanah yang dijaminkan debitur kepada pihak KPKLN. Agunan tersebut sudah didaftarkan ke KPKNL Bekasi dan Pelaksanaan Lelang ditetapkan pada tanggal 16 Desember 2019.

Lelang tersebut akhirnya dimenangkan oleh Agus Wahyudi sebagai pemenang Lelang atas Lelang Eksekusi selain barang yang dirampas untuk negara berupa : sebidang tanah berikut bangunan seluas $84 \mathrm{~m} 2$, sesuai SHGB No 2663/Jayamukti an Henda terletak du Jalan Puma VII B/39/RW 08 Desa Jayamukti, Kecamatan Cikarang Pusat, Kabupaten Bekasi. Dengan harga lelang sebesar Rp.316.000.000, bertempat diKPKNL Bekasi, Jl. Sersan Aswan No. 8D, Bekasi Timur, Bekasi.

Berdasarkan keterangan diatas pelelangan tersebut masuk kedalam Lelangan Eksekusi. Dimana Lelang Eksekusi yang dilaksanakan pada asset debitur berada pada ranah Lelang Eksekusi atas Hak Tangungan sebagaimana dimaksud Pasal 6 UndangUndang Nomor Tahun 1996 tentang Hak Tanggungan Atas Tanah Beserta Benda-Benda yang Berkaitan dengan Tanah ('UU Hak Tanggungan") apabila objek jaminan berupa tanah dan/ata bangunan atau Lelang Eksekusi atas Fidusia sebagaimana dimaksud Pasal

${ }^{9}$ Yunita, Astri Maria S.H., M.H 'Prosedur Lelang Jaminan Kredit ' 07 October 2016 
29 ayat (1) huruf b Undang-Undang Nomor 42 Tahun 1999 tentang Jaminan Fidusia ('UU Fidusia") apabila objek jaminan berupa barang bergerak, seperti kendaraan.

Lelang Eksekusi biasanya memiliki metode agar memudahkan debitur memahami maksud dari Lelang Eksekusi antara lain bahwa metode Lelang Eksekusi berdasarkan Undang-Undang Hak Tanggungan dan Undang-Undang Fidusia ialah melalui Parate Eksekusi, dimana Parate Eksekus ini dilaksanakan berdasarkan titel eksekutorial yang terdapat dalam Sertipikat Hak Tanggungan tata cara yang ditentukan dalam peraturan perundang-undangan dan metode ini memiliki prinsip tanpa campur tangan Pengadilan yaitu eksekusi dilakukan tanpa perintah Ketua Pengadilann Negeri.

\section{KESIMPULAN}

Bank Perkreditan Rakyat (BPR) adalah lembaga keuangan yang menghimpun dana dari masyarakat dalam bentuk simpanan dan menyalurkannya dalam bentuk kredit. Salah satu bentuk kredit yang dimiliki oleh Bank Perkreditan Rakyat (BPR) adalah pinjaman angsuran yang berlaku baik bagi nasabah legal maupun non legal, Perjanjian kredit antara bank dan nasabah mengacu pada Pasal 1754 KUH Perdata, Dalam perjanjian kredit bank, hal yang sangat penting adalah tentang jaminan kepada pemberi pinjaman atau bank (letter of credit agency), dan jaminan terkait kredit merupakan salah satu syarat untuk mendapatkan pengajuan kredit. Agunan di sini tidak hanya digunakan untuk barang, tetapi juga menjadi milik debitur, dan bisa juga dalam bentuk bagunan tidak berwujud.

Salah satu dampak utama dari kredit macet adalah kerugian yang dialami bank, beberapa bank terancam bangkrut. Kredit macet atau kredit bermasalah adalah pinjaman yang sulit dilunasi karena faktor atau faktor yang disengaja atau karena kondisi yang tidak dapat ditanggung oleh debitur. Terjadinya kredit macet biasanya disebabkan oleh dua hal, antara lain kreditor (bank) dan debitur Jika pengadilan menetapkan bahwa debitur telah melanggar kontrak, maka debitur (pelanggan) akan mengeksekusi agunan. Dasar wanprestasi, jika pengadilan memutuskan debitur wanprestasi maka jaminan yang diberikan debitur (nasabah) akan dieksekusi. Bahwasannya sebelum dilakukan eksekusi Nasabah diberikan Surat Pemberitahuan kesatu, kedua dan menelpon debitur agar melunasi angsuran yang sedang dijalani, jika debitur tidak merespon pihak bank akan mendatangkan kerumahnya dan jika rumah tersebut kosong tanpa penghuni pihak bank akan memberikan Surat Peringakatan (SP). 
KRTHA BHAYANGKARA | Volume 15 Number 1, June 2021

\section{SARAN}

Seharusnya pihak Bank Perkreditan Rakyat (BPR) lebih teliti dalam memberikan pinjaman kepada nasabah, agar tidak terulang lagi kemacetan dalam pembayaran kredit yang menyebabkan kerugian bagi bank, dengan nasabah melakukan kemacetan dalam pembayaran membuat bank tidak pecaya lagi dalam memberikan pinjaman. Dan untuk nasabah seharusnya lebih tidak melakukan pembayaran kredit dengan jangka waktu yang cepat sehingga nasabah tidak keteter dalam pembayaran kredit dan barang yang dijaminkan untuk kredit tidak dilelang oleh pihak Bank Perkreditan Rakyat (BPR).

\section{DAFTAR PUSTAKA}

\section{Buku}

Sembiring, Sentosa. Hukum Perbankan (Bandung, Mandar Maju, 2012)

\section{Jurnal}

Novi, Amanita. "Bank dan Lembaga Keuangan Lain.” Jumal Universitas Negri Yogyakarta, Bab 4: 1-3

Susetiyo Weppy, Pitono. “Tinjauan Yuridis Penyelesaian Kredit Macet pada Bank Perkreditan Rakyat Berkah Patok Kediri, Jawa Timur”. Universitas Islam Balitar 9 No. 2 (2019) 50-51.

Sambe, N Newfriend. "Fungsi Jaminan Terhadap Pemberian Kredit Oleh Pihak Bank Menurut Undang-Undang Nomor 10 Tahun 1998”. Lex Crimen 5, No.4 (2016): 76-77

Diab, Ashadi. "Perjanjian Kredit pada Bank Perkreditan Rakyat." Institut Agama Islam Negeri Kendari 10 No. 1(2017) 3-6.

Sambe, Newfriend N. "Fungsi Jaminan Terhadap Pemberian Kredit oleh pihak Bank Menurut Undang-Undang Nomor 10 Tahun 1998.” Lex Crimen 5 Nomor 4 (2016)

\section{Internet}

Hadijah, Siti "Prosedur Penyitaan Aset yang Dilakukan Oleh Bank" 3 September 2020 Yunita, Astri Maria S.H., M.H 'Prosedur Lelang Jaminan Kredit ' 07 October 2016 PT. BPR Karya Bakti Sejahtera "Cara Pinjam Uang di Bank Perkreditan Rakyat (BPR)." 9 Mei 2019 